\title{
THE CLINICAL SIGNIFICANCE OF INDOMETHACIN-PROBENECID INTERACTION
}

\author{
P.M. BROOKS, M.A. BELL, R.D. STURROCK, J.P. FAMAEY ${ }^{1}$ \& W.C. DICK \\ Centre for Rheumatic Diseases and University Department of Medicine, Royal Infirmary, Glasgow G4 OSF
}

1 The effect of the addition of probenecid to oral and rectal regimes of indomethacin was studied in three groups of rheumatoid arthritic patients.

2 The addition of probenecid increases plasma levels of indomethacin given both orally and rectally and significantly reduces the clinical parameters of joint inflammation.

3 The use of probenecid with indomethacin at night may be useful in reducing morning stiffness and pain.

4 Though indomethacin plasma levels are markedly raised during concurrent probenecid therapy remarkably few side effects were observed.

\section{Introduction}

Drug interactions are now being described at an ever increasing rate, but their clinical relevance remains uncertain (Dollery, 1973), Probenecid has been shown to increase indomethacin blood concentrations by reducing renal tubular secretion (Skieth, Simkin \& Healey, 1967). Indomethacin and probenecid are often used concurrently in the treatment of gout. However, the clinical significance of the higher blood levels of indomethacin is not known. Since the monitoring of response of acute gout is difficult and since gouty arthritis is a relatively rare disease, especially in Scotland (Boyle \& Buchanan, 1971), we thought it of interest to study the clinical response of higher blood levels of indomethacin during probenecid therapy in patients with rheumatoid arthritis where the clinical response can be more easily monitored (Ritchie, Boyle, McInnes, Jasani, Dalakos, Grieveson \& Buchanan, 1968; Lee, Webb, Anderson \& Buchanan, 1973; Deodhar, Dick, Hodgkinson \& Buchanan, 1973).

\section{Methods}

Three groups of patients with sero-positive rheumatoid arthritis, as defined by the diagnostic criteria of the American Rheumatism Association (Ropes, Bennett, Cobb, Jacox \& Jessar, 1959) were studied. Eighteen were female and ten were male. The mean age was 47 years with a range of

1 Present address: Universite Libre de Bruxelles, Clinique Physiotherapique et Rheumatologique, Rue Haute 322, Bruxelles.
33 years to 61 years. The mean duration of arthritis was 2.1 years (range 0.8 to 3.2 years). All patients studied were sero-positive for rheumatoid factor.

\section{Group 1}

Twelve patients who had been receiving indomethacin $(50 \mathrm{mg})$ for at least 2 months were seen after an overnight fast. Indomethacin $(50 \mathrm{mg})$ was given by mouth and blood was taken at 1, 2, 3 and $4 \mathrm{~h}$ after ingestion. The blood was collected in lithium-heparin tubes, centrifuged for $15 \mathrm{~min}$ at $2000 \mathrm{rev} / \mathrm{min}$ and the supernatant stored.

\section{Group 2}

Ten patients who were taking indomethacin $(50 \mathrm{mg})$ orally three times a day for at least 2 months were requested to chart the degree of their joint pain daily using a pain-assessment form (Lee et al., 1973). They were also requested to record the duration of their morning stiffness. Probenecid $(500 \mathrm{mg})$ orally twice daily was added to the indomethacin regime and treatment was continued for 2 weeks.

An articular index of joint tenderness (Ritchie et al., 1968) and grip strength measurement (Lee, Baxter, Dick \& Webb, 1974) were recorded at the beginning and at the end of the 2 week probenecid treatment period.

\section{Group 3}

Six patients who were taking indomethacin 
suppositories $(100 \mathrm{mg})$ at night were studied at $07.00 \mathrm{~h}$ on 2 days before and 2 days after probenecid $(500 \mathrm{mg})$ given orally at night had been added to the treatment regime. Measurements of articular index, pain score, grip strength and duration of morning stiffness were made each morning and venous blood was withdrawn for the estimation of the plasma indomethacin concentration.

The indomethacin concentration in the plasma was measured by a double extraction spectrofluorometric method extracting into heptane and then sodium carbonate by the method described by Hucker, Dacchei, Cox, Brodie \& Cantwell (1966) and modified by Emori, Champion, Bluestone \& Paulus (1973).

A water blank and two plasma standards containing indomethacin $(1 \mu \mathrm{g} / \mathrm{ml}$ and $5 \mu \mathrm{g} / \mathrm{ml})$ were analysed with each set of determinations. No interference by probenecid on the absorbance reading of indomethacin was seen when probenecid was added in concentrations of $30 \mathrm{mg} / 100 \mathrm{ml}$. Reproducibility was found to decline for levels of indomethacin less than $1 \mu \mathrm{g} / \mathrm{ml}$ and hence these figures are only recorded as $<1.0 \mu \mathrm{g} / \mathrm{ml}$.

Statistical analysis of the results was carried out using the Student's $t$ Test.

\section{Results}

\section{Group 1}

The mean plasma levels of indomethacin before and after the addition of probenecid are seen in Fig. 1 and Table 1. Comparing the results by a Student's $t$ Test the difference in plasma levels is statistically highly significant $(P<0.0005)$ for each of the results where comparison was possible. These significant changes in plasma concentrations were accompanied by a significant change in articular index but not in grip strength (Table 2).

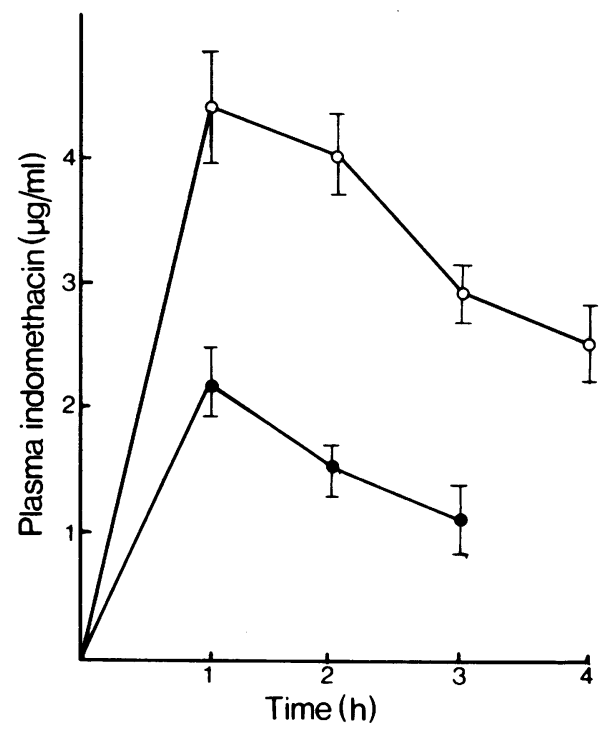

Fig. 1 Plasma indomethacin profile following $50 \mathrm{mg}$ orally before $(\bullet)$ and after $(0)$ probenecid $(500 \mathrm{mg})$ twice daily for 1 week.

\section{Group 2}

The results are summarized in Table 3 . The change in The results are summarized in Table 3. The change in articular index and morning stiffness were highly significant. However, although there was a reduction in pain the difference was not significant.

\section{Group 3}

The results of this group are summarized in Table 4. A comparison was made between the means of the various parameters tested on two consecutive days before addition of probenecid to

Table 1 Indomethacin plasma profile before and after probenecid

Time after treatment (h)

\section{Treatment}

Indomethacin concentration $(\mu \mathrm{g} / \mathrm{ml})$

Indomethacin concentration with probenecid $(\mu \mathrm{g} / \mathrm{ml})$

$P$ value
1

$2.27 \pm 0.2$
$4.44 \pm 0.43$
$<0.0005$

2

$1.59 \pm 0.14$

$4.05 \pm 0.32$

$<0.0005$
3

$1.14 \pm 0.08$

$2.93 \pm 0.26$

$<0.0005$

Mean \pm s.e. mean, $n=12$. 
the mean value on the two consecutive days after addition of probenecid. There is a statistically significant difference between the articular index, pain score and time of morning stiffness. There was also an increase in the $07.00 \mathrm{~h}$ indomethacin concentration.

\section{Side effects}

Two patients in Group 1 were withdrawn from the study because of headaches; their plasma indomethacin levels at the time were $<1.0 \mu \mathrm{g} / \mathrm{ml}$ and $2.6 \mu \mathrm{g} / \mathrm{ml}$, respectively.

Two patients in Group 2 complained of light headedness while on the probenecid/indomethacin combination but this did not necessitate their withdrawal from the trial.

\section{Discussion}

Indomethacin is currently one of the most widely used non-steroidal anti-inflammatory agents with nearly two-and-a-half achievement of peak plasma levels is delayed when the drug is taken with food (Champion, Paulus, Mongan, Okun, Pearson \& achievement of peak plasma levels is delayed when the drug is taken with food (Champion, Paulus, Morgan, Okun, Pearson \& Sarkisson, 1973). Peak plasma levels occur $0.5-2 \mathrm{~h}$ after ingestion but there is considerable between patient variation, although plasma profiles show a high degree of reproducibility in the same patient (Brooks, unpublished data). In human plasma indomethacin is present as the free compound and is highly bound to plasma proteins.

Table 2 Clinical indices for study 1 (Mean \pm s.e. mean, $n=12$ )

$\begin{array}{lccc} & \text { Indomethacin } & \begin{array}{c}\text { Indomethacin with } \\ \text { probenecid }\end{array} & \text { P Value } \\ \text { Articular index } & 17.6 \pm 2.8 & 12.5 \pm 1.1 & <0.05 \\ \begin{array}{l}\text { Grip strength }(\mathrm{mm} \mathrm{Hg}) \\ \quad \text { Right arm }\end{array} & 121 \pm 13.3 & 120 \pm 14.4 & \text { N.S. } \\ \quad \text { Left arm } & 97.9 \pm 9.8 & 102.1 \pm 11.3 & \text { N.S. }\end{array}$

Table 3 Clinical indices for study 2 (Mean \pm s.e. mean, $n=10$ )

$\begin{array}{lccl} & \text { Indomethacin } & \begin{array}{c}\text { Indomethacin with } \\ \text { probenecid }\end{array} & \text { P value } \\ \text { Articular index } & 24.7 \pm 2.3 & 18.3 \pm 2.15 & <0.0005 \\ \text { Pain score } & 2.4 \pm 0.22 & 2.0 \pm 2.5 & <0.1 \\ \text { Morning stiffness (h) } & 3.85 \pm 0.66 & 2.1 \pm 0.37 & <0.005\end{array}$

Table 4 Clinical indices before and after addition of probenecid to indomethacin suppositories for study 3 (Mean \pm s.e. mean, $n=6$ )

$\begin{array}{lccc} & \text { Indomethacin } & \begin{array}{c}\text { Indomethacin with } \\ \text { probenecid }\end{array} & \begin{array}{c}\text { Student's t } \\ \text { test }\end{array} \\ \begin{array}{l}\text { Articular index } \\ \text { Pain score }\end{array} & 13.8 \pm 4.7 & 9.5 \pm 4.2 & <0.025 \\ \begin{array}{l}\text { Grip strength }(\mathrm{mm} \mathrm{Hg}) \\ \quad \text { Right arm }\end{array} & 2.3 \pm 0.25 & 1.28 \pm 0.3 & <0.01 \\ \quad \begin{array}{l}\text { Left arm } \\ \text { Morning stiffness (h) }\end{array} & 135 \pm 24 & 141 \pm 23 & <0.05 \\ \begin{array}{l}\text { Indomethacin plasma } \\ \text { levels }(07.00 \mathrm{~h})(\mu \mathrm{g} / \mathrm{ml})\end{array} & 139 \pm 28 & 145 \pm 34 & \mathrm{~N} . \mathrm{S} . \\ \quad 2.12 \pm 0.6 & 1.06 \pm 0.43 & <0.05 \\ \quad<1.0 & 1.6 \pm 0.143 & \end{array}$


Recent studies suggest that indomethacin may be metabolized in man (Duggan, Hoggans, Kwan \& McMahon, 1972), and although excreted in the faeces the main route of elimination is by the kidneys; $4 \mathrm{~h}$ after an oral dose most being recovered either unchanged or as the glucoronide (Harman, Meisinger, Davis \& Kuehl, 1964).

In this study we have confirmed the observations of Skieth et al. (1968), that there is approximately double the blood level of indomethacin during probenecid therapy. In addition, we have shown that this increase occurs after rectal administration of indomethacin as well as with oral administration.

The three separate studies show clearly that the increase in indomethacin blood levels has a clinical effect. In the first study after one week's therapy of probenecid and indomethacin the articular index of joint tenderness fell significantly. There was no change in grip strength, but this is known to be a relatively insensitive parameter (Deodhar $e t$ al., 1973). Similarly, after 2 weeks' therapy with probenecid and indomethacin there was lessening in pain, articular index of joint tenderness and morning stiffness. These differences did not reach statistical significance with pain, but did with the other indices. In the third study using indomethacin suppositories statistically significant improvement was observed in pain, articular index,

\section{References}

BOARDMAN, P.L. \& HART, F.D. (1965). Indomethacin in the treatment of acute gout. The Practitioner, 194, 560-565.

BOYLE, J.A. \& BUCHANAN, W.W. (1971). Clinical Rheumatology, p. 219. Oxford: Blackwell Scientific Publications.

CHAMPION, D.G., PAULUS, H.E., MONGAN, E., OKUN, R., PEARSON, C.M. \& SARKISSON, E. (1972). The effect of aspirin on serum indomethacin. Clin. Pharmac. Ther., 13, 239-244.

DEODHAR, S.D., DICK, W.C., HODGKINSON, R. \& BUCHANAN, W.W. (1973). Measurement of clinical response to anti-inflammatory drug therapy in rheumatoid arthritis. $Q$. $J$. Med., N.S. 42, 166, 387-401.

DOLLERY, C.T. (1973). Pharmacokinetics-master or servant? Eur. J. Clin. Pharmac., 6, 1-2.

DUGGAN, D.E., HOGGANS, A.F., KWAN, K.C. \& MCMAHON, F.G. (1972). The metabolism of indomethacin in man. J. Pharmac. exp. Ther., 181, 563-575.

EMORI, H.W., CHAMPION, G.D., BLUESTONE, R. \& PAUlUS, H.E. (1973). Simultaneous pharmacokinetics of indomethacin in serum and synovial fluid. Ann. Rheum. Dis., 32, 433-435.

HARMAN, R.E., MEISINGER, M.A.P., DAVIS, G.E. \& KUEHL, F.A. Jr. (1964). The metabolites of indomethacin. A new anti-inflammatory drug. $J$. morning stiffness, and grip strength of the right arm.

It has been shown that indomethacin blood levels are increased by probenecid by reducing tubular secretion of indomethacin (Skieth et al., 1968). This study was performed on patients with rheumatoid arthritis, but presumably a clinical effect could also have been demonstrated in acute gout where indomethacin has been shown to be effective (Boardman \& Hart, 1965).

Four of the 28 patients in the present study manifested side effects from indomethacin, which required discontinuation of the drug in two patients. This is a somewhat low incidence of side effects (Boardman \& Hart, 1965) in view of the high blood levels of indomethacin, but may be due to the relatively short duration of the study. However, it is conceivable that probenecid might counteract the side effects of indomethacin, and further studies are being undertaken to determine whether this might be the case.

The authors wish to thank Professor W. Watson Buchanan for helpful advice and criticism. In addition we wish to acknowledge financial support from the Arthritis and Rheumatism Council for Research in Great Britain, the National Fund for Crippling Diseases, and Merck, Sharp and Dohme, Ltd.

Reprint requests should be addressed to P.M.B.

Pharmac. exp. Ther., 143, 215-220.

HUCKER, H.B., DACCHEI, A.G., COX, S.V., BRODUE, D.A. \& CANTWELL, N.H.R. (1966). Studies on the absorption, distribution and excretion of indomethacin in various species. J. Pharmac. exp. Ther., 153, 237-249.

LEE, P., BAXTER, A., DICK, W.C. \& WEBB, J. (1974). An assessment of grip strength measurement in rheumatoid arthritis. Scand. J. Rheumatology, 3, 17-23.

LEE, P., WEBB, J., ANDERSON, J. \& BUCHANAN, W.W. (1973). Method for assessing therapeutic potential of anti-inflammatory drugs in rheumatoid arthritis. Br. med. J., 2, 685-688.

RITCHIE, D.M., BOYLE, J.A., MCINNES, J.M., JASANI, M.K., DALAKOS, T.G., GRIEVESON, P. \& BUCHANAN, W.W. (1968). Clinical studies with an articular index for the assessment of joint tenderness in patients with rheumatoid arthritis. $Q . J$. Med. N.S. 37, 393-406.

ROPES, M.W., BENNETT, G.A., COBB, S., JACOX, R. \& JESSAR, R.A. (1959). Revision of diagnostic criteria for rheumatoid arthritis. Ann. Rheum. Dis., 18, 49.

SKEITH, M.D., SIMKIN, P.A. \& HEALEY, L.A. (1968). The renal excretion of indomethacin and its inhibition by probenecid. Clin. Pharmac. Ther., 9, 89-93.

(Received June 3, 1974) 